\title{
18. GEOCHEMISTRY AND PETROLOGY OF PLEISTOCENE ASH LAYERS ERUPTED AT LAS CAÑNAS EDIFICE (TENERIFE) ${ }^{1}$
}

\author{
Uta Rodehorst, ${ }^{2,3}$ Hans-Ulrich Schmincke, ${ }^{2}$ and Mari Sumita ${ }^{2}$
}

\begin{abstract}
Sixty-eight fallout trachytic to phonolitic ash layers recovered from Sites 953, 954, and 956 during Leg 157 are interpreted as a result of explosive eruptions of the Las Cañadas edifice on Tenerife. Their biostratigraphic ages range from 0.3 to 3.8 Ma. Tephra layers consist dominantly of highly vesicular pumice and 1-10 vol\% phenocrysts. Alkali feldspar occurs in almost all layers; but plagioclase, clinopyroxene, amphibole, phlogopite, sphene, Fe-Ti oxides, and hauyne appear in some. Nepheline, hauyne and sodalite occur together in one of the younger (0.4 Ma) layers at Site 953 (Sample 157-953A-2H-5, 148-150 cm). The chemical composition of glass shards, analyzed by electron microprobe in 20 samples changes from trachytic to phonolitic in the time interval between 2 and 0.4 Ma. The concentration of trace elements ( $\mathrm{Ce}, \mathrm{La}, \mathrm{Mn}, \mathrm{Fe}$, and $\mathrm{Zr}$ ) in sphene, analyzed in four layers, is variable. Bulk ash analyses by X-ray fluorescence and inductive coupled plasma mass spectrometry show similar major and trace element patterns for all tephra layers. Although eruptive gaps have been postulated from distribution of volcanic rocks on land, the stratigraphic distribution of submarine ash layers suggests that explosive volcanic activity of the Cañadas volcano on Tenerife was fairly continuous. None of the noneruptive hiatuses postulated between 0.37 and $0.65 \mathrm{Ma}, 0.85$ and 1.2 $\mathrm{Ma}$ and 1.6 and 2.0 Ma in the Cañadas series on land were confirmed. Apparently fallout ash layers in the marine environment provide a more reliable record of volcanic activity on land.
\end{abstract}

\section{INTRODUCTION}

Pico de Teide (3718 meters above sea level [masl]), the third highest oceanic volcano on Earth, is arguably the most explosive one. Compared with its two mighty counterparts, Mauna Loa (4170 masl) and Mauna Kea (4206 masl) on the island of Hawaii, both of which are basaltic in composition, the volcanic rocks of the Las Cañadas edifice are almost entirely composed of lavas and pyroclastics of evolved phonolitic to trachyphonolitic composition. The cone of Pico de Teide rises $\sim 1700 \mathrm{~m}$ from a caldera whose present bottom is at $\sim 2000$ masl and whose semicircular walls rise up to $600 \mathrm{~m}$. Pico de Teide itself appears to be composed mostly of basalts covered by a thin layer of basaltic lavas. The caldera walls are composed largely of lavas, minor amounts of ignimbrites, and fallout tephra layers whose age ranges from $\sim 3 \mathrm{Ma}$ at the discontinuously exposed Lower Group at the base to $\sim 0.18 \mathrm{Ma}$ at the Diego Hernandez Formation in the northeastern part of the caldera wall (Ancochea et al., 1990; Marti et al., 1989, 1994). The caldera wall, which is visible for $27 \mathrm{~km}$, provides almost continuous outcrop of the precaldera rocks. Our aim in drilling tephra layers from Tenerife during Ocean Drilling Program (ODP) Leg 157 was to find answers to the following questions:

1. When did explosive activity of the Las Cañadas edifice, Pico de Teide, and its older neighbor Pico Viejo begin?

2. Was explosive activity during the evolution of Cañadas volcano continuous or discontinuous?

3. Can tephra layers from Deep Sea Drilling Project (DSDP) Site 397 be correlated with those from Sites 955 and 956 ?

4. Do the tephra layers record the mineralogical and geochemical evolution of the Las Cañadas edifice and Pico de Teide?

${ }^{1}$ Weaver, P.P.E., Schmincke, H.-U., Firth, J.V., and Duffield, W. (Eds.), 1998. Proc. ODP, Sci. Results, 157: College Station, TX (Ocean Drilling Program).

${ }^{2}$ GEOMAR Forschungszentrum, Wischhofstrasse 1-3, D-24148 Kiel, Federal Republic of Germany.

${ }^{3}$ Present address: Mineralogisch-Petrographisches Institut, Universität Kiel, Olshausenstr. 40, 24118 Kiel, Federal Republic of Germany. ur@min.uni-kiel.de
5. Can the temporal, chemical, and petrological evolution reflected by the tephra layers be correlated with that of corresponding deposits on land?

Tephra fallout layers in marine sediments are especially suitable for reconstructing the petrologic evolution of volcano-magma systems (e.g., Paterne et al., 1988; Dehn et al., 1991; Straub, 1995; Fisher and Schmincke, 1984). Tephra layers deposited on land are more rapidly eroded and, as in the case of Tenerife, are covered by younger tephra or lava flows. Many lower Pliocene and Pleistocene tephra layers related to the growth and evolution of the Las Cañadas edifice were recovered at Sites 953 through 956 and studied with sedimentologic, geochemical, and petrologic methods. These tephra layers consist dominantly of highly evolved ashes and lapilli younger than 3.8 Ma and older than 0.3 Ma. Hole 955A, $211 \mathrm{~km}$ east of Tenerife, will not be discussed as only one significant tephra layer has been sampled. Here we present preliminary data on the volcanic and petrologic evolution of this large volcanic complex. Basaltic glasses in some of these layers (sideromelane) are discussed in a companion paper (Gurenko and Schmincke, Chap. 25, this volume).

\section{METHODS}

\section{Sample Preparation}

The tephra samples were shock-frozen and then sieved through 63-, 125-, and 250- $\mu \mathrm{m}$ polyester screens and 500- $\mu \mathrm{m}, 1-\mathrm{mm}, 2-\mathrm{mm}$ sieves with distilled water and dried at $40^{\circ} \mathrm{C}$. The altered and lithified samples, and the so-called beach sands that mostly contain skeletal debris from shallow water zones, were excluded. The clean pumice and phenocrysts with a grain size between 250 and $500 \mu \mathrm{m}$ were imbedded in resin, and 20 polished sections were prepared for electron microprobe analysis and microscopic study.

\section{Electron Microprobe}

Electron microprobe analyses were performed on a CAMECA SX 50 microprobe equipped with four spectrometers at GEOMAR, Kiel.

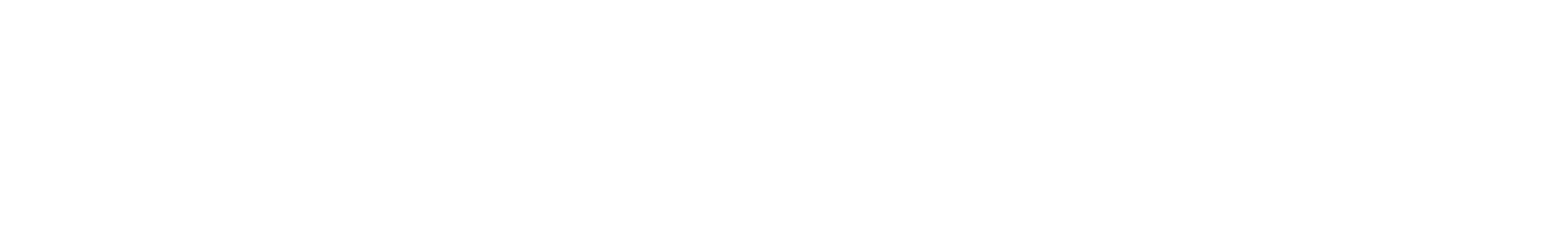


Analytical conditions were $15 \mathrm{kV}$ accelerating voltage and $12 \mathrm{nA}$ sample current for glass and hauyne, $20 \mathrm{nA}$ for feldspar, amphibole, phlogopite, and sphene, and $30 \mathrm{nA}$ for olivine and clinopyroxene. In alkalirich minerals, sodium and potassium were among the first elements analyzed. Sphene is rich in rare earth and other trace elements (light rare earth to $>1 \mathrm{wt} \%$, for example, $\mathrm{Ce}_{2} \mathrm{O}_{3}$ as much as $1.8 \mathrm{wt} \%$ ), which can be measured by microprobe. Synthetic standards (P\&H Developments) for rare earth elements (REE) with $4 \mathrm{wt} \%$ element concentrations were used. To avoid the problem that many L-alpha lines of the different REE undergo (i.e., interference from other X-ray lines), only $\mathrm{La}, \mathrm{Nd}$, and $\mathrm{Ce}$ were analyzed because these have strong lines and clear peaks. In sphene, the REE and $\mathrm{Mn}$ substitute for $\mathrm{Ca}$, whereas $\mathrm{Fe}, \mathrm{Al}, \mathrm{Zr}, \mathrm{V}$, and $\mathrm{Nb}$ substitute for $\mathrm{Ti}$ (Oberti et al., 1991). The elements $\mathrm{Ce}, \mathrm{La}, \mathrm{Nd}$, $\mathrm{Mn}$, and $\mathrm{Fe}$ were measured in sphene from four different ash layers. The standard errors (deviation from expected standard value and the measured average of the standard during several analyses) were Ce: 2.7\%; La: $1.5 \%$; Nd: $3.9 \%$; Mn: $2.4 \%$; and Fe: $0.5 \%$.

\section{Bulk Chemistry}

X-ray fluorescence (XRF) analyses were carried out on clean pumice separates of eight samples where there was sufficient sample material and no visible phenocrysts. We also analyzed one crystalrich sample with basaltic mineralogy (Sample 157-954A-7H-4, 59$61 \mathrm{~cm})$. Inductively coupled plasma mass spectrometry (ICP-MS) analyses of 35 trace elements were performed on three phenocrystfree pumice samples.

\section{Geochronology}

Alkali feldspar and plagioclase crystals were separated for single crystal dating. The grain size of the crystals was between 500 and 200 $\mu \mathrm{m}$. The ${ }^{40} \mathrm{Ar} /{ }^{39} \mathrm{Ar}$ single crystal laser ages are discussed in a separate paper (Bogaard, Chap. 19, this volume).

\section{ANALYTICAL RESULTS \\ Core Descriptions}

All felsic fallout tephra layers of upper Pliocene/Pleistocene age are assumed to have erupted from the Las Cañadas edifice on Tenerife, based on their bio- and magnetostratigraphic ages, ranging from $>3.8$ to $0.3 \mathrm{Ma}$ (Brunner et al., Chap. 9 , this volume). During this time interval, no volcanic activity (La Gomera) or almost exclusively mafic activity is recorded from the other Canary Islands (Lanzarote, Fuerteventura, La Palma, and Gran Canaria; Coello et al. 1992). The ages of the phonolithic tephra layers in Barranco de Guadeque (Gran Canaria), whose age maybe between 3 and 2 Ma are presently being determined.

The combined total thickness of all Pliocene/Pleistocene felsic volcaniclastic layers in Hole 956A is $\sim 250 \mathrm{~cm}$ (26 tephra layers), in Holes 954A and 954B $\sim 170 \mathrm{~cm}$ (35 tephra layers), and in Hole 953A $\sim 52 \mathrm{~cm}$ (nine tephra layers). Felsic tephra layers occur down to 122 meters below seafloor (mbsf; Hole 953A), 140 mbsf (Holes 954A, 954B), 118 mbsf (Hole 955A) and 100 mbsf (Hole 956A), respectively. Below 110 mbsf, the core recovery at Hole 954B was only $\sim 50 \%$, and no sediments ranging in age from 1 to $2.5 \mathrm{Ma}$ are present in Hole 954B. Most likely, the number of ash layers is much higher at this locality beeing close to Tenerife. In summary, the bulk of the ash evidently was transported to the northeast to Sites 954 and 953 as few ash layers occur at Site 956 southeast of the island even though this Site is closer to Tenerife (Fig.1). Table 1 summarizes biostratigraphic age (Brunner et al., Chap. 9, this volume), macroscopic descriptive information for all samples (Schmincke, Weaver, Firth, et al., 1995), and median and sorting. The tephra layers contain pumice as a main component next to glass shards, lithic fragments, microlites and $1-10$ vol\% phenocrysts. These constituents are mixed with variable amounts of nannofossil

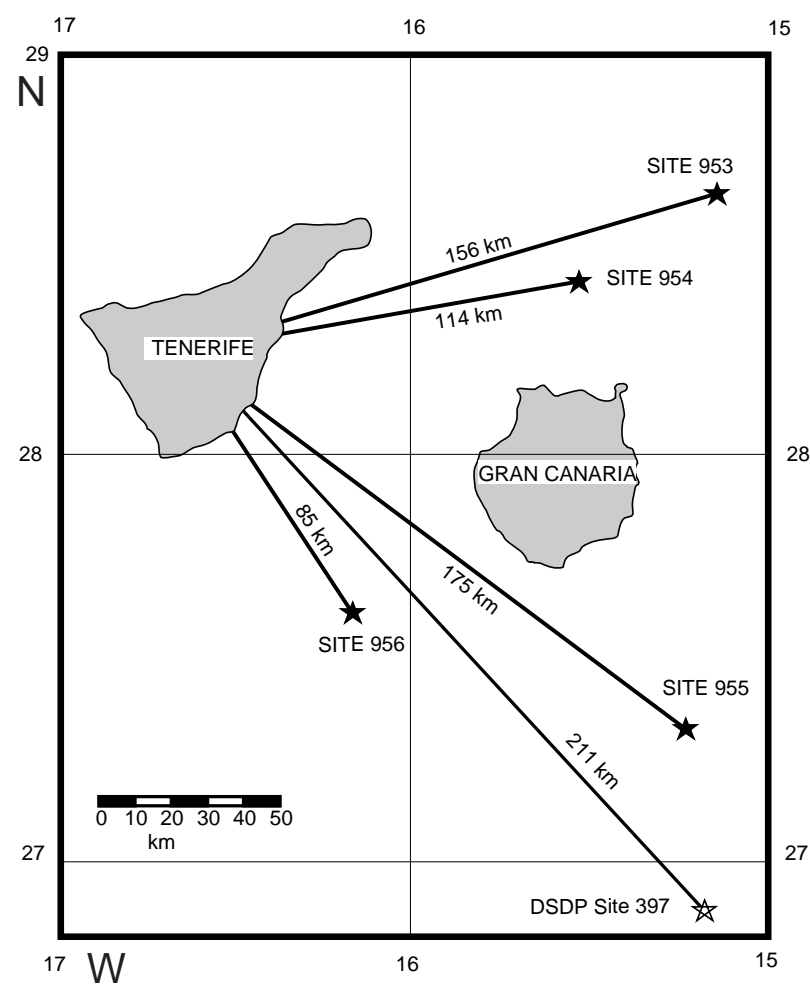

Figure 1. Locations of drill sites around Gran Canaria, showing distances to the approximate center of the Las Cañadas caldera on Tenerife.

mud, foraminifers and skeletal debris. The most common phenocryst is alkali feldspar. Plagioclase, amphibole, biotite, sphene, hauyne, sodalite, pyroxene, nepheline, and Fe-Ti-oxides occur in minor amounts. The pumice is fresh, except in the deeper cores from Hole 954 (Samples 157-954B-7R-2, 22-25 cm, and 12R-1, 92-93 cm) and Hole 956 (Sample 157-956A-11H-5, 125-127 cm). Some more strongly altered layers occur in Hole 956 (Sample 157-956A-3H-5, 100-112 cm; Table 1). To compare Sites 953, 954, and 956 with observations made on land, biostratigraphic ages (Schmincke, Weaver, Firth, et al., 1995) have been plotted together with the K/Ar and ${ }^{40} \mathrm{Ar} /{ }^{39} \mathrm{Ar}$ ages from the caldera wall (Marti et al., 1994; Fig.2).

\section{Phenocryst Composition}

Pumice and phenocrysts of feldspar, phlogopite, amphibole, pyroxene, olivine, hauyne, and sphene were analyzed by microprobe in 20 polished thin sections. The oldest analyzed samples are from Hole 956A (1.6-2 Ma). The samples studied from Hole 954A range between 0.43 and $1 \mathrm{Ma}$, those of Hole 953A from 0.38 and $0.7 \mathrm{Ma}$. One layer sampled in Hole 953A is $1 \mathrm{Ma}$ (Sample 157-953A-7H-3, 70-72 $\mathrm{cm}$ ) and another is $1.55 \mathrm{Ma}$ (Sample 157-953A-11H-5, 39-40 cm). The mineral abundance for the three sites vs. age is illustrated in Figure 3.

Alkali feldspars was analysed in seven thin sections (Fig. 4) and do not vary in composition with time. Two primary fallout ashes from Tenerife (Samples 157-953A-2H-4, 77-79 cm, and 157-954A-9H-2, $145-147 \mathrm{~cm})$ are characterized by plagioclase. Two samples from Hole 956 (Samples 157-956A-7H-6, 70-76 cm, and 6H-2, 124-124 $\mathrm{cm})$ contain plagioclase and olivine. The related pumices are rounded, and sorting is low, which indicate reworking.

Hauyne occurs in $~ 30 \%$ of the tephra layers, mostly in the younger tephra $(<0.65 \mathrm{Ma})$ and in tephra older than 1.7 Ma. Sample 157953A-2H-5 $(148-150 \mathrm{~cm})$ contains nepheline, sodalite, and hauyne. 
Table 1. List of samples, grain size analyses, and macroscopic descriptions.*

\begin{tabular}{|c|c|c|c|c|c|c|c|c|c|c|}
\hline Label & $\begin{array}{l}\text { Core, section, } \\
\text { interval }(\mathrm{cm})\end{array}$ & Depth & $\begin{array}{l}\text { Biostrat. age } \\
\text { (Ma) }\end{array}$ & $\begin{array}{l}\text { Stderr. } \\
\text { age }\end{array}$ & Sorting & $\begin{array}{l}\text { Median } \\
(\mu \mathrm{m})\end{array}$ & $\begin{array}{c}\text { Thickness } \\
(\mathrm{cm})\end{array}$ & Notes & Deposition & Color \\
\hline & 157-953A- & & & & & & & & & \\
\hline $\begin{array}{l}\text { URO-3-1 } \\
\text { URO-3-2 }\end{array}$ & $\begin{array}{l}1 \mathrm{H}-5,122-124 \\
2 \mathrm{H}-4\end{array}$ & 7.22 & 0.30 & 0.08 & 0.625 & 88 & 73 & Mixed sediment & & Dark gray \\
\hline URO-3-2 & & 12.87 & 0.38 & & - & - & 15 & - & $\mathrm{s}$ & Dark brown \\
\hline URO-3-3 & $5 \mathrm{H}-1,148-150$ & 15.08 & 0.41 & & - & - & 10 & Pumice sand & $\mathrm{p}$ & Gray \\
\hline URO-3-4 & $3 \mathrm{H}-6,143-144$ & 26.03 & 0.56 & & - & - & - & - & & - \\
\hline URO-3-5 & $4 \mathrm{H}-1,71-72$ & 27.31 & 0.57 & & - & - & 8 & Dark crystal vitric ash & & Dark gray \\
\hline URO-3-6 & $5 \mathrm{H}-1,54-56$ & 36.64 & & & - & - & & - & $\mathrm{p}$ ? & Dark green \\
\hline URO-3-7 & $5 \mathrm{H}-1,56-57$ & 36.66 & 0.70 & & 1.650 & 51 & 4 & - & p? & Light green \\
\hline URO-3-8 & $5 \mathrm{H}-1,57-58$ & 36.67 & & & - & - & & - & p? & Light green \\
\hline URO-3-9 & $7 \mathrm{H}-3,70-72$ & 58.80 & 1.00 & & 1.900 & 38 & 2.5 & Homogeneous fine volcanic ash & p? & Medium brown \\
\hline URO-3-10 & $11 \mathrm{H}-5,39-40$ & 99.49 & 1.55 & & 2.025 & 44 & 8 & Disperse ash layer & $\mathrm{p}$ & Yellow green \\
\hline URO-3-11 & $12 \mathrm{H}-6,54-55$ & 110.64 & 1.70 & & 2.000 & 31 & 2 & - & & - \\
\hline URO-3-12 & $14 \mathrm{H}-1,83-84$ & 122.43 & 1.86 & & 1.850 & 134 & 2 & Disperse ash layer & & - \\
\hline & $157-954 \mathrm{~A}-$ & & & & & & & & & \\
\hline URO-4-1 & $3 \mathrm{H}-1,88-89$ & 11.38 & 0.30 & 0.04 & 1.500 & 26 & 5 & - & $\mathrm{p}$ & Dark olive green \\
\hline URO-4-2 & $3 \mathrm{H}-1,132-133$ & 11.82 & 0.30 & & - & - & 40 & - & & Dark brown \\
\hline URO-4-3 & $3 \mathrm{H}-2,92-93$ & 12.92 & 0.31 & & 1.500 & 74 & 9 & - & & Light green brown \\
\hline URO-4-4 & $3 \mathrm{H}-2,110-111$ & 13.10 & 0.32 & & - & - & - & - & & Light brown \\
\hline URO-4-5 & $3 \mathrm{H}-6,139-145$ & 19.39 & 0.39 & & 1.250 & 274 & - & Pumice sand with granule pumice clasts & $\mathrm{s}$ & - \\
\hline URO-4-6 & $4 \mathrm{H}-3,43-44$ & 23.43 & 0.43 & & - & - & - & - & & Gray green \\
\hline URO-4-7 & $4 \mathrm{H}-6,87-88$ & 28.37 & 0.49 & & 1.750 & 36 & 0.5 & - & & Light green \\
\hline URO-4-8 & $4 \mathrm{H}-6,120-122$ & 28.70 & 0.49 & & 0.900 & 177 & - & - & & - \\
\hline URO-4-9 & $6 \mathrm{H}-5,58-60$ & 45.58 & 0.68 & & 1.750 & 37 & - & - & & - \\
\hline URO-4-10 & $6 \mathrm{H}-5,67-69$ & 45.67 & & & 2.500 & 31 & & - & & - \\
\hline URO-4-11 & $6 \mathrm{H}-5,71-73$ & 45.71 & 0.68 & & 1.750 & 53 & 10 & - & & - \\
\hline URO-4-12 & $6 \mathrm{H}-5,75-77$ & 45.75 & & & 2.250 & 44 & & Coarse ash & $\mathrm{p}$ & Light green \\
\hline URO-4-13 & $7 \mathrm{H}-1,14-16$ & 48.64 & 0.71 & & - & - & - & - & & - \\
\hline URO-4-14 & $7 \mathrm{H}-1,39-41$ & 48.89 & 0.72 & & 2.300 & 31 & & - & & - \\
\hline URO-4-15 & $7 \mathrm{H}-1,81-85$ & 49.31 & 0.72 & & 2.200 & 31 & 7.5 & - & & Green gray \\
\hline URO-4-16 & $7 \mathrm{H}-2,30-32$ & 50.30 & 0.73 & & - & - & 2 & - & & Dark gray brown \\
\hline URO-4-17 & $7 \mathrm{H}-4,59-61$ & 53.59 & 0.77 & & 0.625 & 149 & 7 & Dark basalt sands & & Dark gray brown \\
\hline URO-4-18 & $8 \mathrm{H}-1,114-116$ & 59.14 & 0.83 & & 1.550 & 22 & - & Disturbed clay & & 20 - \\
\hline URO-4-19 & $8 \mathrm{H}-2,52-54$ & 60.02 & 0.84 & & 2.625 & 134 & - & - & & - \\
\hline URO-4-20 & $8 \mathrm{H}-2,88-90$ & 60.38 & 0.84 & & 2.275 & 19 & 1 & Pumice sand & $\mathrm{p}$ ? & Gray \\
\hline URO-4-21 & $8 \mathrm{H}-4,61-63$ & 63.11 & 0.88 & & - & - & 1 & Volcanic ash & $\mathrm{p}$ ? & - \\
\hline URO-4-22 & $8 \mathrm{H}-7,11-13$ & 67.11 & 0.92 & & 1.900 & 31 & 1.5 & Volcanic ash & p? & Green gray \\
\hline URO-4-23 & $9 \mathrm{H}-1,139-140$ & 68.89 & 0.94 & & 0.700 & 109 & 6 & Interbeds & & _ \\
\hline URO-4-24 & $9 \mathrm{H}-2,140-141$ & 70.40 & 0.96 & & 2.050 & 36 & - & - & & Green gray \\
\hline URO-4-25 & $9 \mathrm{H}-2,143-144$ & 70.43 & 0.96 & & 1.850 & 31 & - & - & & Green gray \\
\hline URO-4-26 & $9 \mathrm{H}-2,145-147$ & 70.45 & 0.96 & & 2.025 & 37 & 6.5 & - & & Green gray \\
\hline URO-4-27 & $9 \mathrm{H}-3,7-8$ & 70.57 & 0.96 & & 1.900 & 27 & 1 & - & & Green gray \\
\hline URO-4-28 & $9 \mathrm{H}-3,140-141$ & 71.90 & 0.97 & & 0.950 & 102 & 5 & Dark basaltic sand & & Black \\
\hline URO-4-29 & $9 \mathrm{H}-4,33-34$ & 72.33 & 0.98 & & 1.700 & 250 & 17 & Pumice & & - \\
\hline & $157-954 \mathrm{R}-$ & & & & & & & & & \\
\hline URO-4-30 & $4 \mathrm{R}-1,123-125$ & 110.93 & 2.60 & 0.07 & 1.750 & 22 & 24 & Vitric fine ash & & Gray \\
\hline URO-4-31 & $4 \mathrm{R}-1,136-138$ & 111.06 & 2.60 & & 1.800 & 19 & - & - & & Light gray \\
\hline URO-4-32 & $4 \mathrm{R}-2,4-6$ & 111.24 & 2.61 & & 1.900 & 18 & - & - & & Light gray \\
\hline URO-4-33 & $4 \mathrm{R}-2,35-37$ & 111.55 & 2.61 & & 1.850 & 354 & 19 & - & $\mathrm{p}$ & Gray \\
\hline URO-4-34 & $4 \mathrm{R}-2,89-91$ & 112.09 & 2.62 & & 1.800 & 25 & 4 & Mixed sediment with vitric ash & & Green gray \\
\hline URO-4-35 & $5 \mathrm{R}-3,45-47$ & 122.75 & 2.79 & & 2.100 & 24 & 1 & _ & & _ \\
\hline URO-4-36 & $5 \mathrm{R}-3,71-73$ & 123.01 & 2.79 & & - & - & 1 & Coarse ash layer & & - \\
\hline URO-4-37 & $6 \mathrm{R}-4,133-135$ & 134.83 & 2.97 & & - & - & 2 & - & & Yellow green \\
\hline URO-4-38 & $7 \mathrm{R}-2,22-25$ & 140.32 & 3.06 & & - & - & - & Zeolized tuff & & Gray \\
\hline URO-4-39 & $12 \mathrm{R}-1,92-93$ & 187.82 & 3.79 & 0.23 & - & - & - & Claystone & & - \\
\hline & $157-956 \mathrm{~A}-$ & & & & & & & & & \\
\hline URO-6-1 & $3 \mathrm{H}-3,86-92$ & 19.46 & 0.58 & & - & - & - & Beach sand & $\mathrm{s}$ & Gray \\
\hline URO-6-2 & $3 \mathrm{H}-5,23-29$ & 21.83 & 0.67 & & - & - & - & Beach sand & $\mathrm{s}$ & Gray \\
\hline URO-6-3 & $3 \mathrm{H}-5,100-106$ & 22.60 & 0.72 & & - & - & - & Palagonitic ash & & Dark orange brown \\
\hline URO-6-4 & $3 \mathrm{H}-5,108-109$ & 22.68 & 0.72 & & - & - & - & Palagonitic ash & & Dark orange brown \\
\hline URO-6-5 & $3 \mathrm{H}-5,111-112$ & 22.71 & 0.72 & & - & - & 40 & Palagonitic ash & & Dark orange brown \\
\hline URO-6-6 & $4 \mathrm{H}-7,1-3$ & 34.11 & 1.12 & & - & - & 3 & Pumice clasts from $0-3 \mathrm{~cm}$ & & Gray \\
\hline URO-6-7 & $5 \mathrm{H}-4,85-86$ & 39.95 & 1.34 & & - & - & - & Pumice lithic sand & $\mathrm{s}$ & Pale gray \\
\hline URO-6-8 & $5 \mathrm{H}-4,92-94$ & 40.02 & 1.34 & & - & - & - & Pumice lithic sand & $\mathrm{s}$ & Pale gray \\
\hline URO-6-9 & $5 \mathrm{H}-4,118-132$ & 41.78 & 1.40 & & - & - & 6.5 & Massive pumice sand & & Black gray banded \\
\hline URO-6-10 & $6 \mathrm{H}-2,120-122$ & 46.80 & 1.56 & & - & 22 & 5 & Pumice sand & & Gray \\
\hline URO-6-11 & $6 \mathrm{H}-2,122-124$ & 46.82 & 1.56 & & 2.750 & 38 & 2 & Pumice sand & & Gray \\
\hline URO-6-12 & $6 \mathrm{H}-2,124-126$ & 46.84 & 1.56 & & 2.125 & 54 & 0.5 & Pumice sand & $\mathrm{s}$ & Gray \\
\hline URO-6-13 & $6 \mathrm{H}-2,128-130$ & 46.88 & 1.56 & & 1.550 & 18 & - & Vitric silt & & Gray \\
\hline URO-6-14 & $7 \mathrm{H}-1,135-137$ & 54.95 & 1.80 & & 2.225 & 10 & 1.5 & Crystal sand with pumice & & Dark gray \\
\hline URO-6-15 & $7 \mathrm{H}-2,84-86$ & 55.94 & 1.83 & & 2.125 & 36 & 1 & - & & - \\
\hline URO-6-16 & $7 \mathrm{H}-3,56-58$ & 57.16 & 1.87 & & - & - & 6 & Volcanic glass & & - \\
\hline URO-6-17 & $7 \mathrm{H}-5,105-107$ & 60.65 & 1.96 & & 1.500 & 13 & 5 & Pumice sand & & Dark green gray \\
\hline URO-6-19 & 7H-5, 107-109 & 60.67 & 1.96 & & - & - & 4 & Pumice sand & & Dark green gray \\
\hline URO-6-18 & $7 \mathrm{H}-6,70-76$ & 61.80 & 1.99 & & - & - & 65 & Coarse sand & $\mathrm{s}$ & Speckled gray \\
\hline URO-6-20 & $7 \mathrm{H}-\mathrm{CC}, 7-9$ & 63.23 & 2.04 & & 2.250 & 22 & 6 & Pumice sand & & Dark gray \\
\hline URO-6-21 & $7 \mathrm{H}-\mathrm{CC}, 11-13$ & 63.27 & 2.04 & & 1.950 & 63 & 1 & Pumice sand & & dark gray \\
\hline URO-6-22 & $8 \mathrm{H}-5,72-74$ & 69.82 & 2.21 & & 3.000 & 44 & 5 & Foram pumice fine sand & & - \\
\hline URO-6-23 & $8 \mathrm{H}-5,144-146$ & 70.54 & 2.22 & & 2.750 & 44 & 17 & Foram pumice & & Gray \\
\hline URO-6-24 & $9 \mathrm{H}-1,33-34$ & 72.93 & 2.27 & & - & - & 2.5 & - & & Green gray \\
\hline URO-6-25 & $9 \mathrm{H}-1,38-39$ & 72.98 & 2.27 & & 2.150 & 36 & 0.5 & - & & Green gray \\
\hline URO-6-26 & $9 \mathrm{H}-1,63-64$ & 73.23 & 2.27 & & - & - & 2 & Coarse rounded pumice sand & $\mathrm{s}$ & Dark gray \\
\hline URO-6-27 & $9 \mathrm{H}-2,22-27$ & 74.32 & 2.29 & & 2.350 & 354 & 30 & Lithic pumice sand, rounded & $\mathrm{s}$ & - \\
\hline URO-6-28 & $9 \mathrm{H}-2,90-92$ & 75.00 & 2.33 & & 1.675 & 77 & 8 & Vitric silt & $\mathrm{p}$ & Dark green \\
\hline URO-6-29 & $9 \mathrm{H}-3,15-21$ & 75.75 & 2.33 & & - & - & 14 & Pumice sand & $\mathrm{p}$ & Gray green \\
\hline URO-6-30 & $9 \mathrm{H}-3,106-107$ & 76.66 & & & 0.625 & 88 & & & & \\
\hline URO-6-31 & $9 \mathrm{H}-3,107-108$ & 76.67 & 2.35 & & 0.575 & 88 & 9 & Volcanic ash & $\mathrm{p}$ & Green gray \\
\hline URO-6-32 & $9 \mathrm{H}-3,111-113$ & 76.71 & & & 1.650 & 41 & & & & \\
\hline
\end{tabular}


Table 1 (continued).

\begin{tabular}{|c|c|c|c|c|c|c|c|c|c|c|}
\hline Label & $\begin{array}{l}\text { Core, section, } \\
\text { interval }(\mathrm{cm})\end{array}$ & Depth & $\begin{array}{l}\text { Biostrat. age } \\
\text { (Ma) }\end{array}$ & $\begin{array}{l}\text { Stderr. } \\
\text { age }\end{array}$ & Sorting & $\begin{array}{c}\text { Median } \\
(\mu \mathrm{m})\end{array}$ & $\begin{array}{l}\text { Thickness } \\
(\mathrm{cm})\end{array}$ & Notes & Deposition & Color \\
\hline URO-6-33 & $11 \mathrm{H}-2,68-70$ & 93.78 & 2.69 & & - & - & 1 & Volcanic ash & & Green gray \\
\hline URO-6-34 & $11 \mathrm{H}-2,110-113$ & 94.20 & & & - & - & & & & - \\
\hline URO-6-35 & $11 \mathrm{H}-2,113-114$ & 94.23 & 2.70 & & - & - & 6 & Pumice lapilli & & - \\
\hline URO-6-36 & $11 \mathrm{H}-2,114-115$ & 94.24 & & & 1.850 & 22 & & & & - \\
\hline URO-6-37 & $11 \mathrm{H}-5,125-127$ & 98.85 & 2.77 & & 1.775 & 36 & 10 & - & & - \\
\hline
\end{tabular}

Notes: $*$ = from Schmincke, Weaver, Firth, et al. (1995). Biostrat. age $=$ biostratigraphic age, and Stderr. $=$ standard error $($ Brunner et al., Chap. 9 , this volume $) .-=$ no data determined, $\mathrm{s}=$ secondary, and $\mathrm{p}=$ primary.

Figure 2. Biostratigraphic ages with standard deviations for Sites 953, 954, and 956 (Brunner at al., Chap. 9, this volume) compared with the ages of the units in the caldera wall (Marti et al., 1994), which were determined by ${ }^{40} \mathrm{Ar} /{ }^{39} \mathrm{Ar}$ and $\mathrm{K}-\mathrm{Ar}$ age dating.

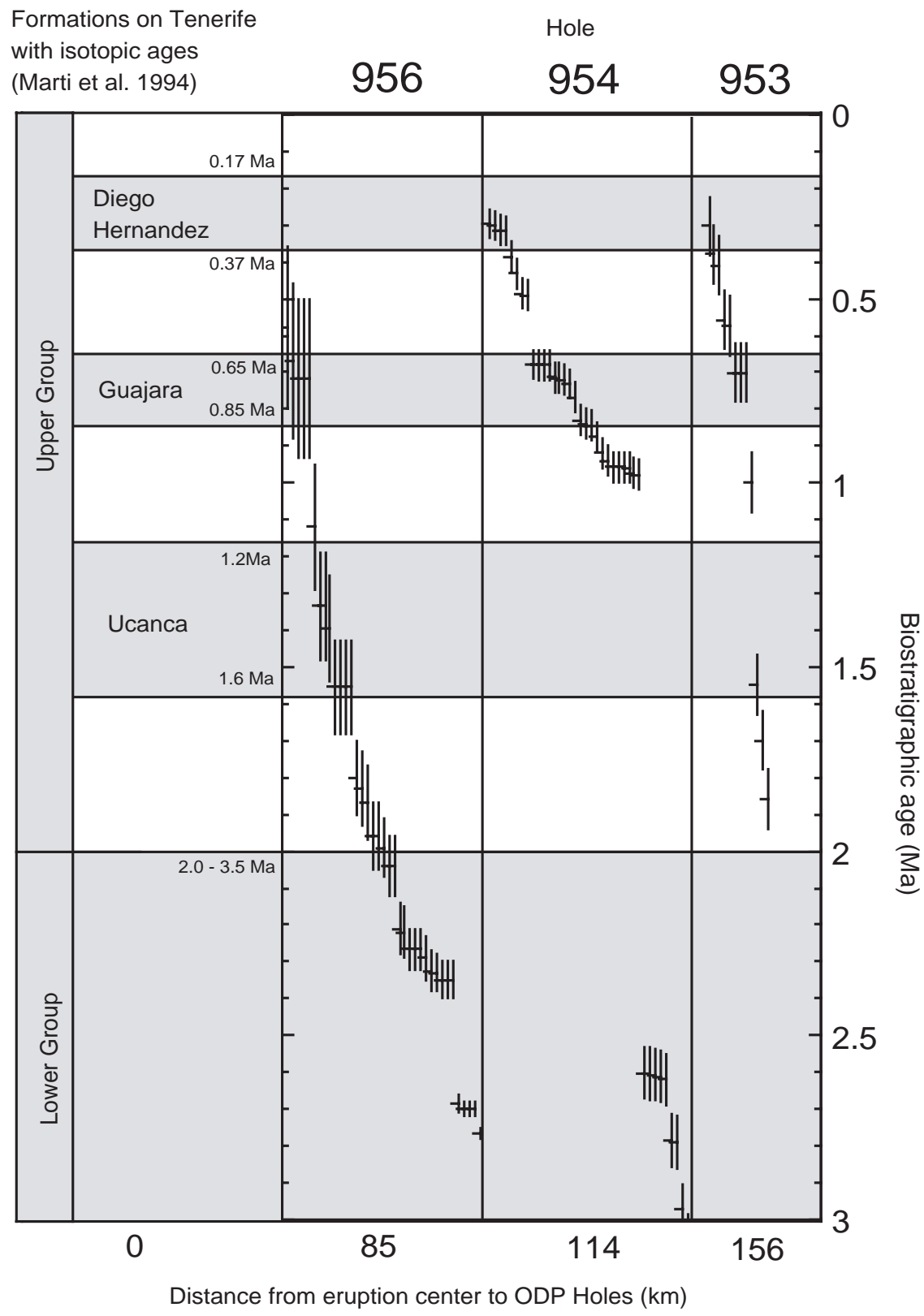

Sphene is common in the submarine ash layers from Tenerife. Sphene of Sample 157-953A-14H-1 (83-84 cm) differs chemically to the three other layers (Fig. 5). The amount of $\mathrm{Ce}, \mathrm{Nd}$, and $\mathrm{La}$ is low, and the Ti content varies with each sphene grain correlating with the Fe content. The three other samples substitute REE on Ca position in various amounts. An increase in the concentration of $\mathrm{La}, \mathrm{Ce}, \mathrm{Fe}$, and Mn with increasing age is shown for these layers (Fig. 5).
The composition of glass shards was analyzed in 20 samples from 2 to $0.4 \mathrm{Ma}$. Up to 20 analyses were performed for each grain mount. Representative data are listed in Table 2, and the results are plotted in Figures 6 and 7. The data were normalized volatile-free to $100 \%$. The totals show no significant age dependence and the same trends (in-

\section{Chemical Composition of Glass Shards}


Site 956

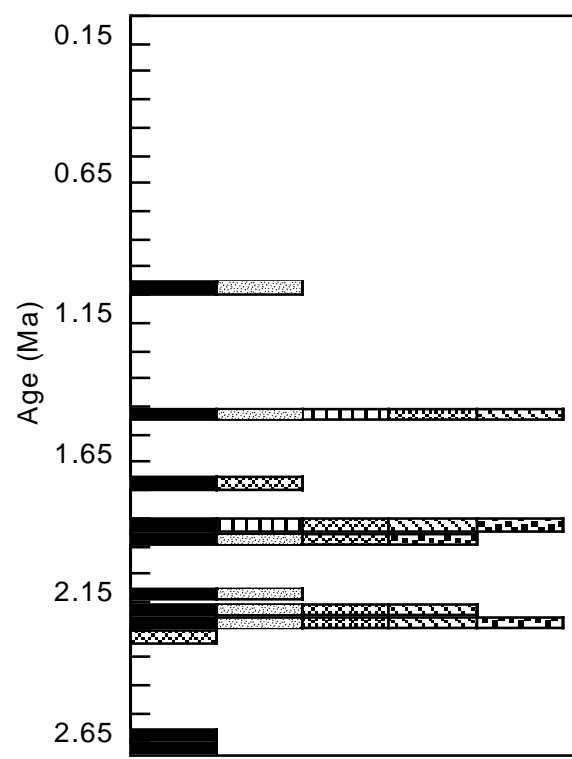

ए Olivine

$\square \quad$ Amphibole

- Pyroxene

$\begin{array}{llll}\square & \text { Nepheline } & \square & \text { Olivine } \\ \square & \text { Hauyn } & \square & \text { Amphibole } \\ \square & \text { Sphene } & \square & \text { Pyroxene }\end{array}$

Biotite
Site 954

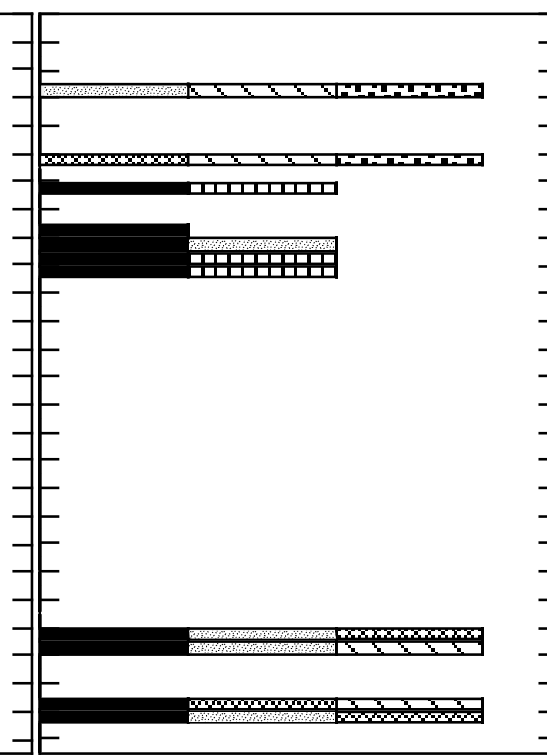

Qualitative occurence

phenocrysts except feldspar
Site 953

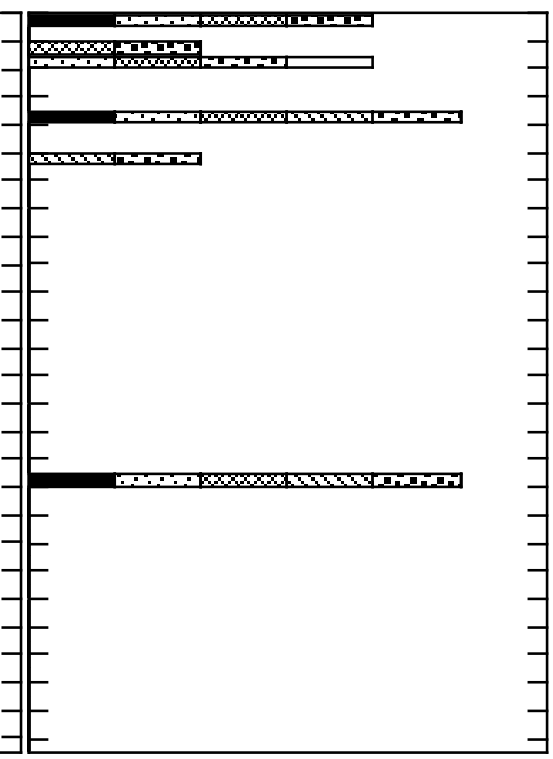

Figure 3. Mineral distribution vs. age of tephra layers from Sites 953, 954, and 956. Alkali feldspar is not shown, occurring in almost all samples. No quantitative estimation is shown, because estimation is based on the thin sections with different grain-sized fractions. One bar represents whether one sort of mineral occurs.

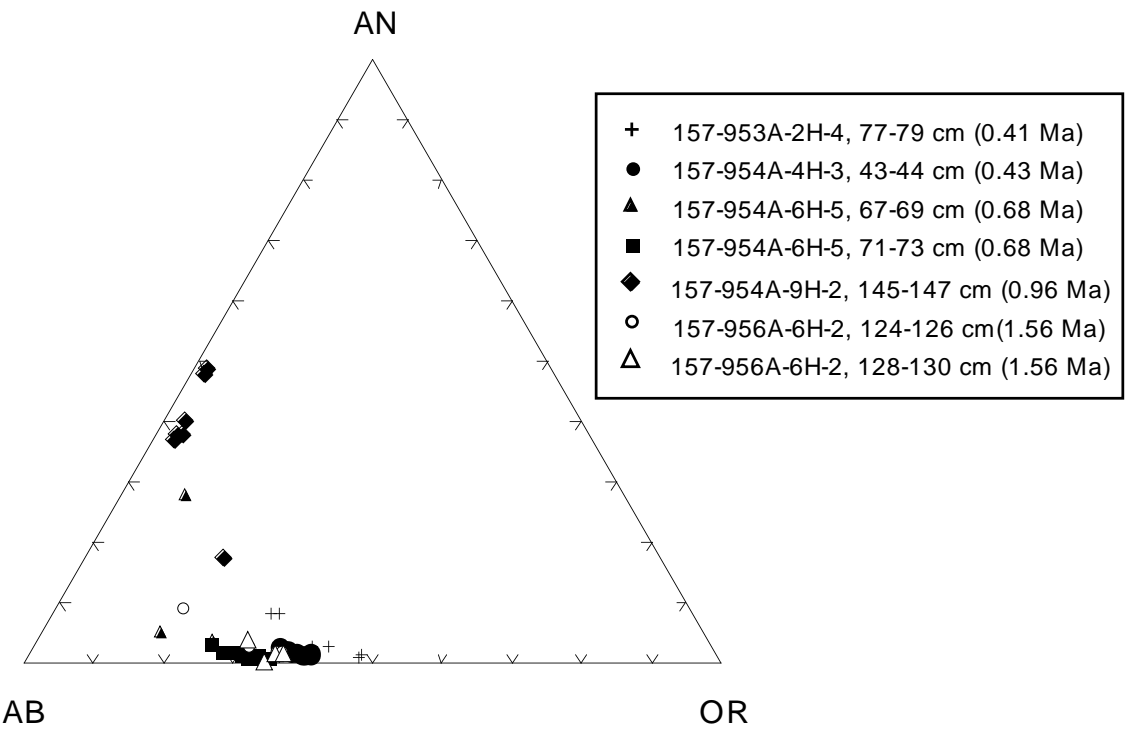

Figure 4. Feldspar compositions from individual layers, measured by electron microprobe. Each symbol corresponds to the average of 10-20 spots of a single feldspar grain. creasing total alkalis with decreasing age) as the raw data (Fig. 8). This suggest that errors because of normalization and thus hydratization should be minor. The submarine ashes are trachytic and phonolitic. Trachyandesitic glass is rare: (1) two grains in Sample 157954A-6H-5, 67-69 cm, that were taken from the top of a 10-cm-thick layer (10-14 measurement points for each grain); (2) glass from Sample $157-953 \mathrm{~A}-11 \mathrm{H}-5,39-40 \mathrm{~cm}$; and (3) one pumice grain from the ash Sample 157-956A-6H-2, 124-126 cm, which is probably reworked.

The composition of the glasses changes with time from trachyte to phonolite (Fig. 6). $\mathrm{Al}_{2} \mathrm{O}_{3}$ decreases with increasing $\mathrm{SiO}_{2}$; the $\mathrm{FeO}$ total and $\mathrm{MnO}$ contents are low and show no significant trends vs. $\mathrm{SiO}_{2}$ (Fig. 7). The glass analyses from ash Sample 157-953A-2H-4 (77-79 $\mathrm{cm})$, ranging from phonolitic to basaltic within a single grain, suggest 

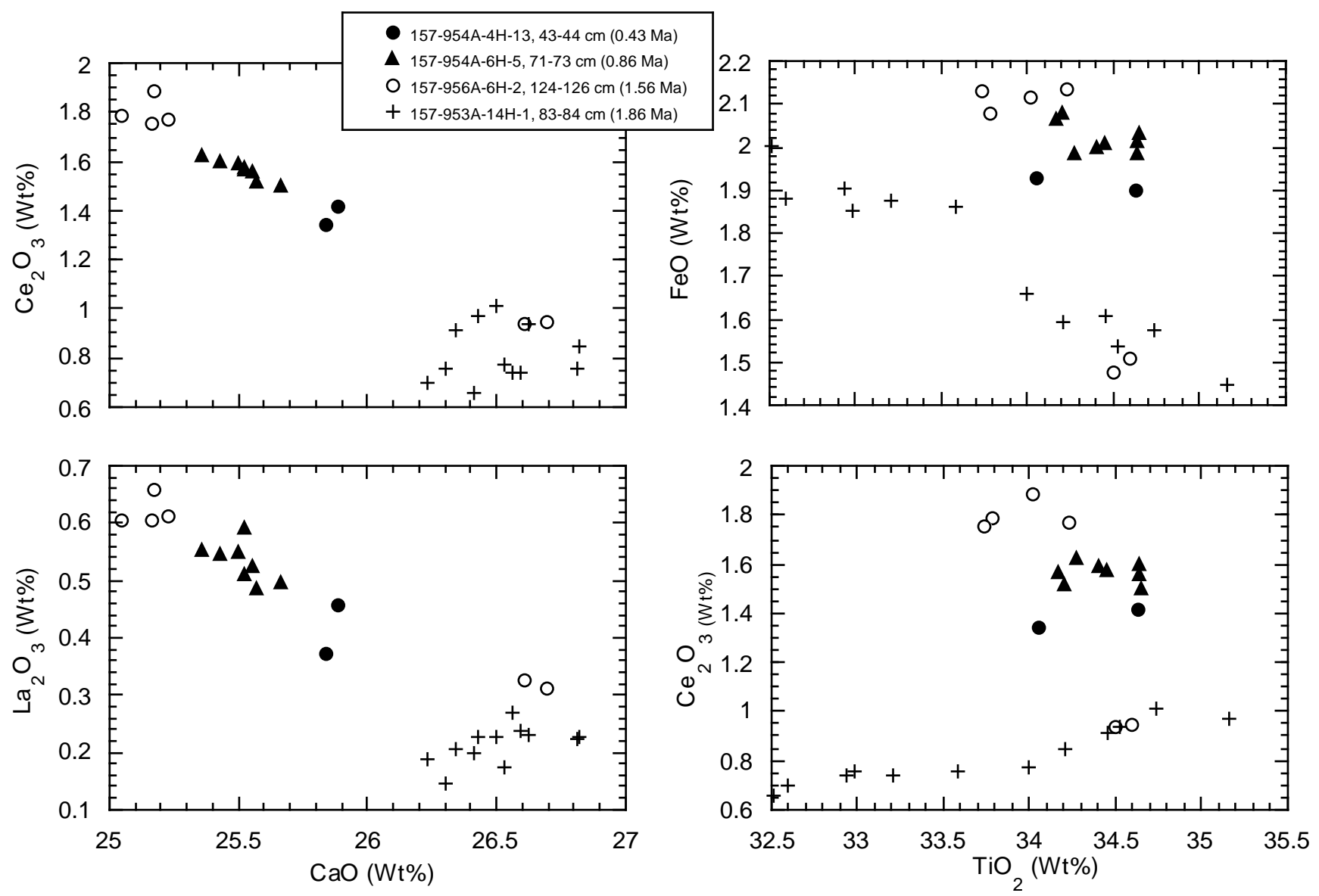

Figure 5. Microprobe analyses of sphene. Each data point corresponds to the average of 10 to 20 spots measured on one grain. The plots of $\mathrm{Ce}_{2} \mathrm{O}_{3}$ and $\mathrm{La}_{2} \mathrm{O}_{3}$ vs. $\mathrm{CaO}$ represent the isomorphic substitution of $\mathrm{Ce}$ and $\mathrm{La}$ on Ca position correlating well in contrast to $\mathrm{Ce}_{2} \mathrm{O}_{3}$ vs. $\mathrm{TiO}_{2}$, suggesting no exchange. Sphene of Sample 157-953A-14H-1, 83-84 cm (1.86 Ma), varies strongly in Ti content and substitutes lower amounts of REEs compared to the other samples.

magma mixing (Fig 9). This is confirmed by the occurrence of plagioclase and olivine phenocrysts. Magma mixing is not unusual on Tenerife as discussed by Wolff (1985) and Wolff et al. (1990).

\section{Trace Element Composition of Glass Shards}

The results of the XRF and ICP-MS analyses are listed in Tables 3 and 4 . The trace element concentrations of analyzed pumice were normalized against OIB (Sun and McDonough, 1989). All samples show similar concentrations and distribution patterns (Fig. 10). Differences are not age dependent. The glasses are strongly depleted in $\mathrm{Sr}, \mathrm{Ba}, \mathrm{P}, \mathrm{Ti}$, and $\mathrm{Sc}$ which is interpreted as being caused by fractionation of feldspar, apatite, sphene and/or Fe-Ti oxides, and pyroxene in different amounts. Sample 954A-7H-4, 59-61 cm (0.77 Ma), represents one of the two basaltic tephra layers. The trace element analyses and the similarity in the enrichment patterns show that practically similar mineral combinations have been fractionated in almost all magmas. These minerals are not always found in the samples that represent the coarse-grained fraction so the phases probably have been enriched in the smaller grain-sized fractions or been fractionated during transport.

\section{Comparison with Land-Based Data and Correlation}

Marti et al. (1994) distinguished two main groups, the Upper and the Lower Group in the Las Cañadas caldera wall. The Lower Group (2-3.5 Ma) has not been studied in detail. The Upper Group was sep- arated into three subunits within the 600-m-thick series exposed in the caldera wall from northeast to southwest: the Diego Hernandez (0.17-0.37 Ma), Guajara (0.65-0.85 Ma), and Ucanca Formations (1.2-1.6 Ma). These volcanic phases are postulated to be separated by periods of quiescence lasting between 0.3 and $0.4 \mathrm{Ma}$. Our data do not corroborate the alternation of volcanically active and inactive phases. Instead, the submarine tephra layers reflect volcanic activity throughout the past 3 m.y. (Fig. 2).

The correlation of individual ash layers from the proximal to the more distal sites as well as to DSDP Site 397 requires more detailed textural and chemical analyses of glass shards and phenocrystic minerals and has not been achieved in the present preliminary study. The problems in correlating ash layers between drill sites are mostly attributed to the missing parts of Hole 954A, whose ash layers should correlate with Hole 953.

\section{DISCUSSION}

Our data allow reconstruction of the chemical evolution of the Cañadas volcanic complex, as most analyzed glasses are fresh. The chemical composition of glasses changes with age from trachytic to phonolitic. These changes in composition of the magma cannot be explained by crystal fractionation. If the phonolitic magma were generated by crystal fractionation from a trachytic parent magma, then $\mathrm{SiO}_{2}-$ rich phases such as alkali feldspar should be fractionated. This fractionation would not, however, result in the enrichment of alkalis, which we 
Table 2. XRF analyses of pumice glass.

\begin{tabular}{|c|c|c|c|c|c|c|c|c|}
\hline Hole: & $953 \mathrm{~A}$ & $954 \mathrm{~A}$ & $954 \mathrm{~A}$ & $954 \mathrm{~A}$ & 954B & $956 \mathrm{~A}$ & $956 \mathrm{~A}$ & $956 \mathrm{~A}$ \\
\hline Core, Section: & $2 \mathrm{H}-4$ & $4 \mathrm{H}-3$ & $7 \mathrm{H}-4$ & $9 \mathrm{H}-2$ & $4 \mathrm{R}-2$ & $9 \mathrm{H}-2$ & $9 \mathrm{H}-3$ & $11 \mathrm{H}-2$ \\
\hline Interval (cm): & $77-79$ & $43-44$ & $59-61$ & $145-147$ & $35-37$ & $22-27$ & $15-21$ & $68-70$ \\
\hline Depth (mbsf): & 12.87 & 23.43 & 53.59 & 70.45 & 111.6 & 74.32 & 75.75 & 93.78 \\
\hline Age (Ma): & 0.38 & 0.43 & 0.77 & 0.96 & 2.61 & 2.29 & 2.33 & 2.69 \\
\hline \multicolumn{9}{|c|}{ Major elements (wt\%) } \\
\hline $\mathrm{SiO}_{2}$ & 55.37 & 54.82 & 44.28 & 59.46 & 58.31 & 57.06 & 58.19 & 55.46 \\
\hline $\mathrm{TiO}_{2}$ & 0.56 & 0.57 & 3.65 & 0.63 & 0.42 & 0.58 & 0.51 & 0.89 \\
\hline $\mathrm{Al}_{2} \mathrm{O}_{3}$ & 18.94 & 17.71 & 14.03 & 16.64 & 17.63 & 16.86 & 17.47 & 16.00 \\
\hline $\mathrm{Fe}_{2}^{2} \mathrm{O}_{3}$ & 3.26 & 3.89 & 12.75 & 3.34 & 3.00 & 3.09 & 3.13 & 3.96 \\
\hline $\mathrm{MnO}$ & 0.173 & 0.178 & 0.173 & 0.268 & 0.239 & 0.175 & 0.167 & 0.212 \\
\hline $\mathrm{MgO}$ & 0.33 & 0.23 & 6.00 & 0.23 & 0.17 & 0.35 & 0.21 & 0.6 \\
\hline $\mathrm{CaO}$ & 1.4 & 2.03 & 10.16 & 0.86 & 0.63 & 1.96 & 1.03 & 4.2 \\
\hline $\mathrm{Na}_{2} \mathrm{O}$ & 8.45 & 8.18 & 3.27 & 7.97 & 7.78 & 6.69 & 7.09 & 6.48 \\
\hline $\mathrm{K}_{2} \mathrm{O}$ & 5.47 & 5.33 & 1.53 & 5.2 & 5.35 & 5.24 & 5.43 & 4.46 \\
\hline $\mathrm{P}_{2} \mathrm{O}_{5}$ & 0.111 & 0.063 & 0.673 & 0.062 & 0.044 & 0.077 & 0.067 & 0.155 \\
\hline $\mathrm{SO}_{3}$ & 0.196 & 1.059 & 0.065 & 0.192 & 0.204 & 0.333 & 0.49 & 0.289 \\
\hline $\mathrm{H}_{2} \mathrm{O}+\mathrm{CO}_{2}$ & 3.87 & 4.38 & 1.98 & 3.48 & 4.53 & 5.42 & 4.43 & 4.79 \\
\hline Total & 98.35 & 98.69 & 98.86 & 98.55 & 98.5 & 98.08 & 98.46 & 97.71 \\
\hline \multicolumn{9}{|c|}{ Trace elements (ppm) } \\
\hline $\mathrm{Sc}$ & 2 & 8 & 26 & 5 & 4 & 5 & 6 & 2 \\
\hline V & 25 & 27 & 214 & $<12$ & $<12$ & $<12$ & 21 & $<12$ \\
\hline $\mathrm{Cr}$ & $<18$ & $<18$ & 241 & $<18$ & $<18$ & $<18$ & $<18$ & $<18$ \\
\hline Co & 7 & $<4$ & 29 & $<4$ & 15 & $<4$ & 9 & $<4$ \\
\hline $\mathrm{Ni}$ & 18 & 20 & 102 & 14 & 17 & 14 & 22 & 18 \\
\hline $\mathrm{Cu}$ & 19 & 60 & 72 & 18 & 24 & 16 & 13 & 16 \\
\hline $\mathrm{Zn}$ & 164 & 125 & 125 & 160 & 152 & 114 & 112 & 138 \\
\hline $\mathrm{Ga}$ & 38 & 33 & 18 & 32 & 34 & 32 & 32 & 29 \\
\hline As & 18 & 22 & $<12$ & $<12$ & $<12$ & 12 & 14 & $<12$ \\
\hline $\mathrm{Rb}$ & 188 & 165 & 24 & 153 & 157 & 155 & 157 & 113 \\
\hline $\mathrm{Sr}$ & 120 & 88 & 947 & 27 & 29 & 149 & 107 & 269 \\
\hline $\mathrm{Y}$ & 23 & 31 & 32 & 48 & 38 & 31 & 29 & 39 \\
\hline $\mathrm{Zr}$ & 1117 & 1033 & 287 & 1156 & 1137 & 1040 & 1026 & 843 \\
\hline $\mathrm{Nb}$ & 195 & 210 & 75 & 241 & 230 & 189 & 183 & 195 \\
\hline Мo & 6 & 5 & 9 & 16 & 20 & 11 & 16 & 12 \\
\hline $\mathrm{Ba}$ & 185 & 86 & 508 & 41 & 137 & 457 & 480 & 195 \\
\hline $\mathrm{La}$ & 154 & 457 & 328 & 419 & 186 & 401 & 427 & 528 \\
\hline $\mathrm{Ce}$ & 130 & 173 & 99 & 247 & 193 & 158 & 166 & 168 \\
\hline $\operatorname{Pr}$ & 19 & 54 & 41 & 60 & 24 & 47 & 49 & 62 \\
\hline $\mathrm{Nd}$ & 32 & 42 & 47 & 82 & 48 & 42 & 39 & 58 \\
\hline $\mathrm{Sm}$ & 11 & $<6$ & 10 & 16 & 9 & 11 & $<6$ & 13 \\
\hline $\mathrm{Pb}$ & 25 & 21 & 7 & 28 & 17 & 21 & 18 & 17 \\
\hline Th & 42 & 33 & $<4$ & 23 & 30 & 22 & 21 & 9 \\
\hline $\mathrm{U}$ & 11 & 8 & $<6$ & $<6$ & 8 & $<6$ & 8 & $<6$ \\
\hline
\end{tabular}

observed. Therefore, a change in composition of the mantle source and thus of the primitive mafic parent magmas from alkali basaltic to nephelinitic is postulated. A similar change from $\mathrm{SiO}_{2}$-saturated to undersaturated derivative magmas between $\sim 13.5$ and $12 \mathrm{Ma}$ on Gran Canaria from the Mogán to the Fataga Group volcanics has been observed (Schmincke and von Rad, 1979; Schmincke, 1982). In addition, this temporal change in source composition may indicate a general change of magma generation from the highly productive shield stage and high melting rates to a migration of the mantle source into the cooler marginal parts of the diapir that may have become increasingly mixed with lithospheric material (Hoernle and Schmincke, 1993).

Because submarine tephra differs mineralogically and geochemically from phonolithic lava flows and pyroclastic rocks on land, correlation remains difficult. Equivalent land deposited tephra is rarely exposed and covered by younger lava flows. Usually the mineral assemblages change during the sedimentation process. This is the reason why the glass and mineral chemistries are most useful for correlations. Because analyzed trace elements of the glasses are not distinctive, only the major elements can be used for a rough classification. Very few geochemical data, in particular of glasses, have been determined from the huge caldera wall. The mineral chemistry, especially the chemical differences in REEs of sphene between individual layers, may be helpful as a marker for correlating the submarine tephra with land deposits in the caldera wall. Depending on the frequency of magma mixing processes in the equivalent time period, Sample 157-953A-2H-4, 77-79 cm, would be easy to identify on land.

The submarine tephra records a continuous explosive volcanic activity of the trachytic and phonolithic Las Cañadas edifice between
3.8 and $0.3 \mathrm{Ma}$. The lack of tephra younger than 0.3 Ma roughly delimits the beginning of the less explosive activity of Pico Viejo and Pico de Teide growing from the base of the Las Cañadas caldera on Tenerife.

\section{ACKNOWLEDGMENTS}

We thank the Deutsche Forschungsgemeinschaft for financial support (Grants SCHM 250/43-3, 61-1). Part of the work was financed by grants from the European Commission. ICP-MS analyses were performed by C.D. Garbe-Schönberg (Geologisches Institut, Universität Kiel). The grain sizes $<63 \mu \mathrm{m}$ were determined on a laser particle analyzer by Takechi Kawahara (Earthquake Research Institute, Tokyo). Many thanks to Susanne Straub and Martin Streck for providing helpful advises. We also thank Petra Gloer, Jürgen Freitag (electron microprobe), Antje Merkau (X-ray fluorescence), and Alex Wülpers (core repository, Bremen) for technical help. We acknowledge James H. Wittke and Gordon Haxel for carefully reviewing the paper.

\section{REFERENCES}

Ancochea, E., Fúster, J.M., Ibarrola, E., Cendrero, A., Coello, J., Hernán, F., Cantagrel, J.M., and Jamond, C., 1990. Volcanic evolution of the island of Tenerife (Canary Islands) in the light of new K-Ar data. J. Volcanol. Geotherm. Res., 44:231-249.

Coello, J., Cantagrel, J.-M., Hernín, F., Fúster, J.-M., Ibarrola, E., Ancochea, E., Casquet, C., Jamond, C., Díaz de Téran, J.-R., and Cendrero, A., 
1992. Evolution of the eastern volcanic ridge of the Canary Island based on new K-Ar data. J. Volcanol. Geotherm. Res., 53:251-274.

Dehn, J., Farrell, J.W., and Schmincke, H.-U., 1991. Neogene tephrochronology from Site 758 of the northern Ninetyeast Ridge: Indonesian Arc volcanism of the past 5 Ma. In Weissel, J., Peirce, J., Taylor, E., Alt, J., et al., Proc. ODP, Sci. Results, 121: College Station, TX (Ocean Drilling Program), 273-298.

Fisher, R.V., and Schmincke, H.-U., 1984. Pyroclastic Rocks: New York (Springer-Verlag).

Hoernle, K., and Schmincke, H.-U., 1993. The role of partial melting in the 15-Ma geochemical evolution of Gran Canaria: a blob model for the Canary Hotspot. J. Petrol., 34:599-627.

Marti, J., Mitjavila, J., and Villa, I., 1989. Stratigraphy and K-Ar ages of the Diego Hernández wall and their significance on the Las Cañadas Caldera Formation (Tenerife, Canary Islands). Terra Nova, 2:148-153.

Marti, J., Mitjavila, J., and Araña, V., 1994. Stratigraphy, structure, age and origin of the Cañadas Caldera (Tenerife, Canary Islands). Geol. Mag., 31:715-727.

Oberti, R., Smith, D.C., Rossi, G., and Caucia, F., 1991. The crystal-chemistry of high-aluminium sphenes. Eur. J. Mineral., 3:777-792.

Paterne, M., Guichard, F., and Labeyrie, J., 1988. Explosive activity of the south Italian volcanoes during the past 80,000 years as determined by marine tephrochonologie. J. Volcanol. Geotherm. Res., 34:153-172.

Schmincke, H.-U., 1982. Volcanic and chemical evolution of the Canary Islands. In von Rad, U., Hinz, K., Sarnthein, M., and Seibold, E. (Eds.), Geology of the Northwest African Continental Margin: Berlin (Springer), 273-306.
Schmincke, H.-U., and von Rad, U., 1979. Neogene evolution of Canary Island volcanism inferred from ash layers and volcaniclastic sandstones of DSDP Site 397 (Leg 47A). In von Rad, U., Ryan, W.B.F., et al., Init. Repts. DSDP, 47 (Pt. 1): Washington (U.S. Govt. Printing Office), 703725.

Schmincke, H.-U., Weaver, P.P.E., Firth, J.V., et al., 1995. Proc. ODP, Init. Repts., 157: College Station, TX (Ocean Drilling Program).

Straub, S., 1995. Contrasting compositions of Mariana Trough fallout tephra and Mariana Island arc volcanics: a fractional crystallization link. Bull. Volcanol., 57:403-421.

Sun, S.-S., and McDonough, W.F., 1989. Chemical and isotopic systematics of oceanic basalts: implications for mantle composition and processes. In Saunders, A.D., and Norry, M.J. (Eds.), Magmatism in the Ocean Basins. Geol. Soc. Spec. Publ. London, 42:313-345.

Wolff, A.J., 1985. Zonation, mixing and eruption of silica-undersaturated alkaline magma: a case study from Tenerife, Canary Islands, Geol. Mag., 6:623-640.

Wolff, J.A., Woerner, G., and Blake, S., 1990. Gradients in physical parameters in zoned felsic magma bodies: implications for evolution and eruptive withdrawal. J. Volcanol. Geotherm. Res., 43:37-55.

Date of initial receipt: 3 July 1996

Date of acceptance: 6 January 1997

Ms 157SR-117 

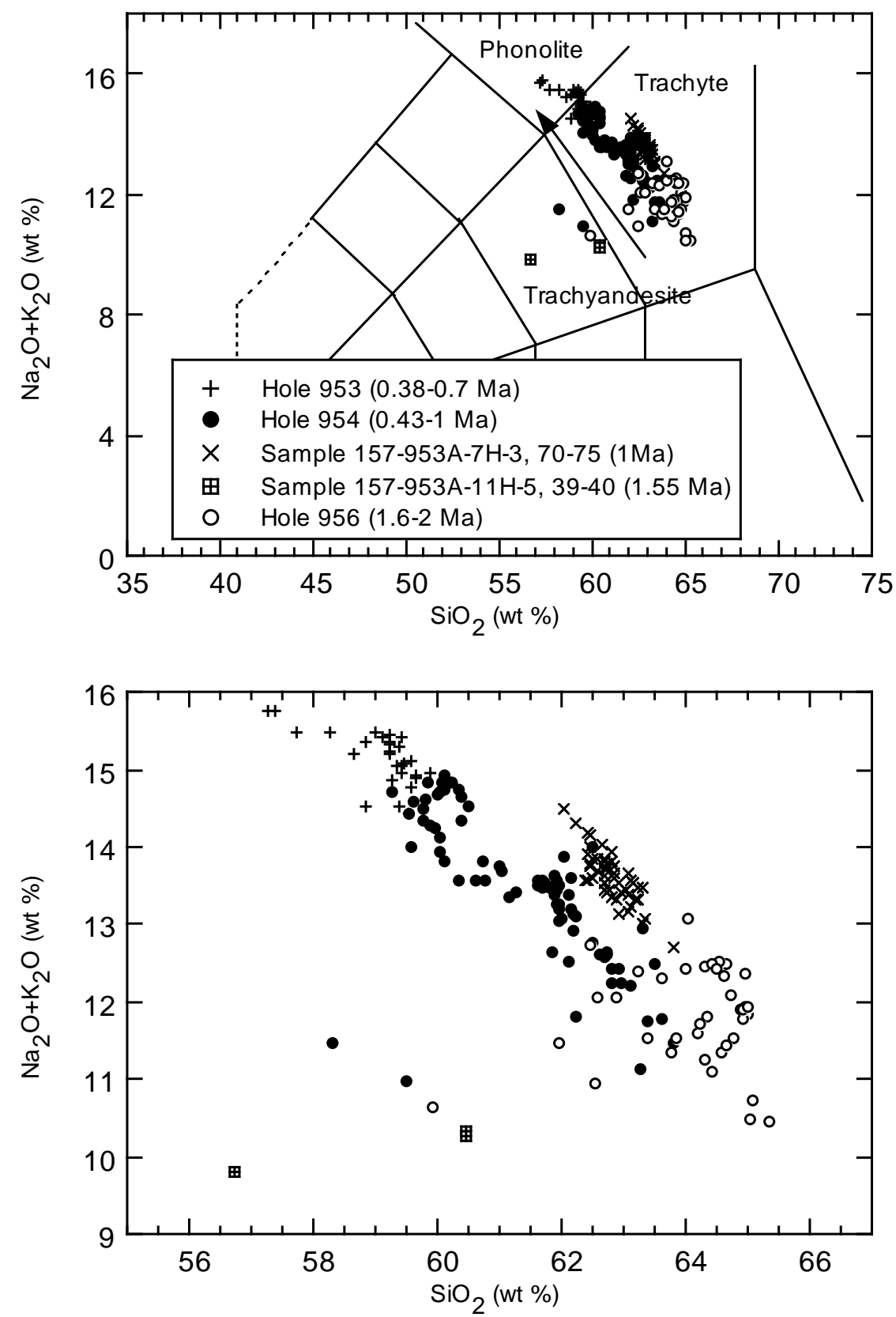

Figure 6. TAS diagram of electron microprobe analyses from pumice glasses, showing the evolution from trachytic to phonolitic composition with age (Site 956 samples are 1.6-2 Ma, Site 954 0.43-1 Ma, and those from Site 953 0.38-1.6 Ma). The compositions are normalized to $100 \%$. The pumice of Sample 157-953A-7H-3, 70-75 cm, containing no phenocrysts, follows the trend, but covers a wide range in composition. 


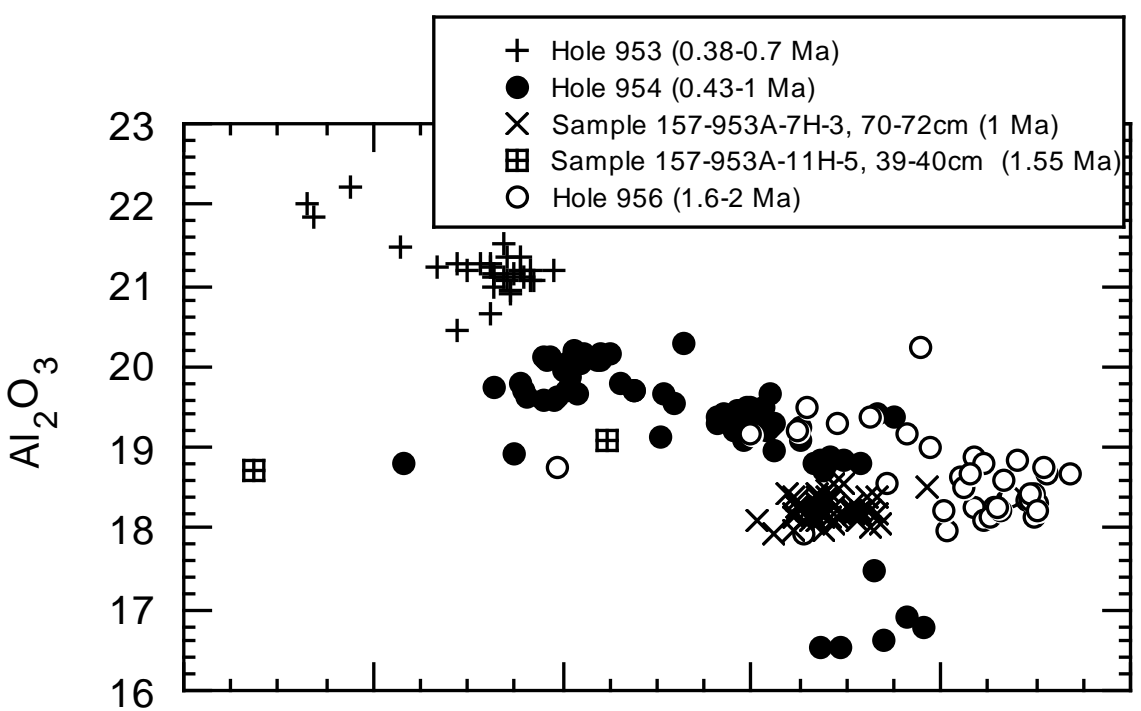

Figure 7. Variation diagrams $\left(\mathrm{MgO}, \mathrm{FeO}^{\text {total }}\right.$, and $\mathrm{Al}_{2} \mathrm{O}_{3}$ vs. $\mathrm{SiO}_{2}$ ) of pumice glass from tephra layers
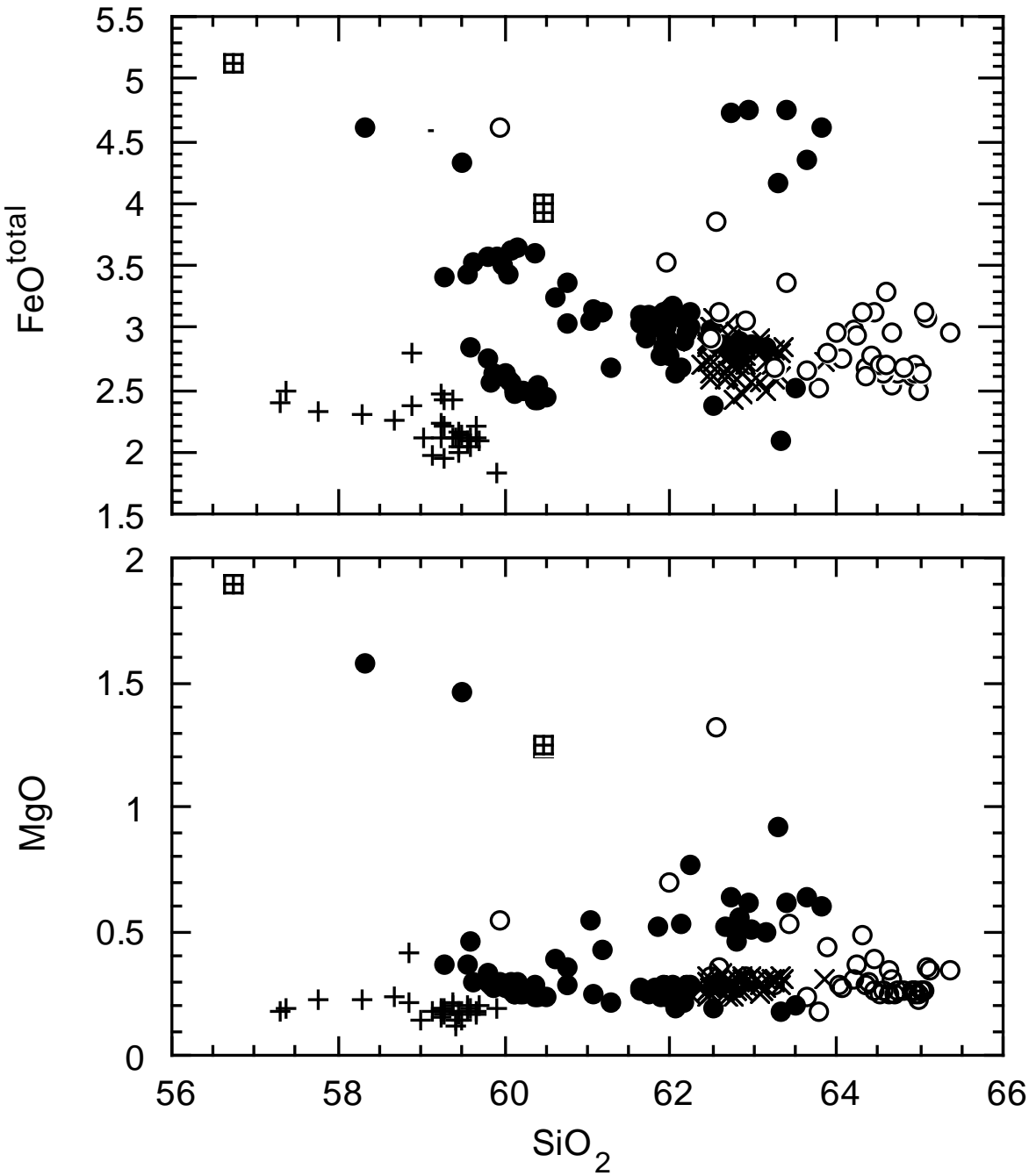

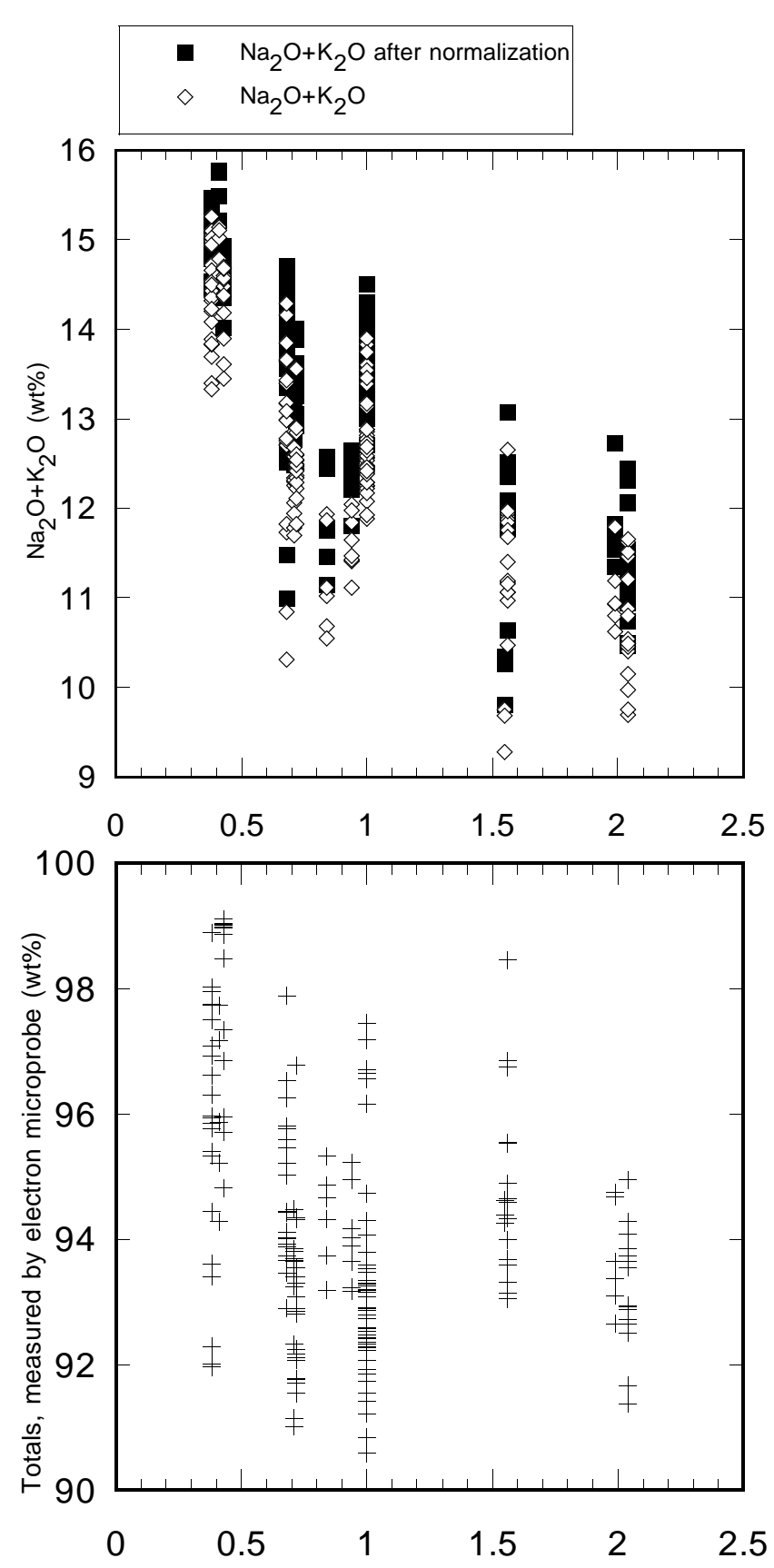

Biostratigraphic age (Ma) (Brunner et al, this volume)

Figure 8. The totals from electron microprobe analyses of the pumice glasses show no significant dependence on age (lower plot). Volatile-free normalization does not therefore influence the trends $\left(\mathrm{Na}_{2} \mathrm{O}+\mathrm{K}_{2} \mathrm{O}\right.$; upper plot).

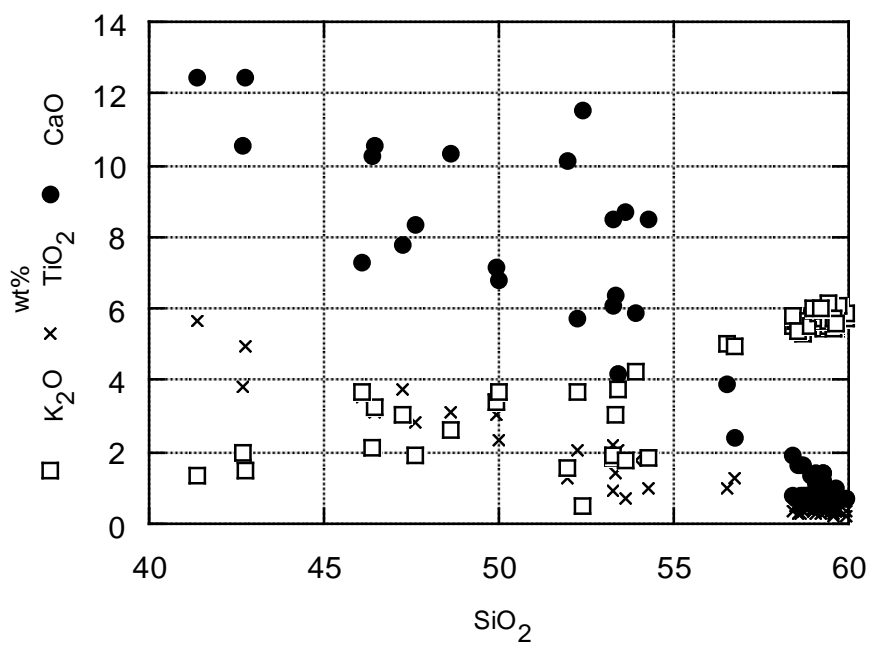

Figure 9. $\mathrm{CaO}, \mathrm{K}_{2} \mathrm{O}$, and $\mathrm{TiO}_{2}$ vs. $\mathrm{SiO}_{2}$ measured by electron microprobe of pumice glass from Sample 157-953A-2H-4, 77-79 cm, indicating magma mixing. 
Table 3. Representative data of glass shards (pumice) and minerals.

\begin{tabular}{|c|c|c|c|c|c|c|c|c|c|c|c|c|c|c|c|c|c|c|c|c|c|c|}
\hline \multirow[t]{2}{*}{$\begin{array}{l}\text { Hole, core, section: } \\
\text { Interval (cm): } \\
\text { Depth }(\mathrm{mbsf}): \\
\text { Mineral: } \\
\text { Points/minerals: }\end{array}$} & \multicolumn{2}{|c|}{$\begin{array}{c}954 \mathrm{~A}-6 \mathrm{H}-5 \\
71-73 \\
45.71 \\
\text { Titanite } \\
128 / 5 \\
\end{array}$} & \multicolumn{2}{|c|}{$\begin{array}{c}\text { 953A-2H-4 } \\
77-79 \\
12.87 \\
\text { Kaersutite } \\
30 / 5 \\
\end{array}$} & \multicolumn{2}{|c|}{$\begin{array}{c}956 \mathrm{~A}-7 \mathrm{H}-6 \\
70-76 \\
61.80 \\
\text { Pyroxene } \\
36 / 6 \\
\end{array}$} & \multicolumn{2}{|c|}{$\begin{array}{c}954 \mathrm{~A}-7 \mathrm{H}-4 \\
59-61 \\
53.59 \\
\text { Pyroxene } \\
33 / 4 \\
\end{array}$} & $\begin{array}{r}\mathrm{Hau} \\
18\end{array}$ & $\begin{array}{l}\text { iyne } \\
3 / 1\end{array}$ & & $\begin{array}{l}\text { alite } \\
4 / 3\end{array}$ & $\begin{array}{r}953 \mathrm{~A} \\
149 \\
15 \\
\mathrm{Nepl} \\
10 \\
\end{array}$ & $\begin{array}{l}2 \mathrm{H}-5 \\
150 \\
09 \\
\text { eline } \\
12 \\
\end{array}$ & & $\begin{array}{l}\text { mice } \\
: / 1\end{array}$ & $\begin{array}{r}\text { Pur } \\
4\end{array}$ & $\begin{array}{l}\text { nice } \\
11 \\
\end{array}$ & $\begin{array}{r}954 \mathrm{~A} \\
71 \\
45 \\
\text { Pur } \\
4 \\
\end{array}$ & $\begin{array}{l}-6 \mathrm{H}-5 \\
-73 \\
.71 \\
\text { mice } \\
4 / 9\end{array}$ & $\begin{array}{r}956 \mathrm{~A}- \\
7 \\
63 \\
\text { Pun } \\
97 \\
\end{array}$ & $\begin{array}{l}7 \mathrm{H}-\mathrm{CC} \\
-9 \\
.23 \\
\text { nice } \\
7 / 9\end{array}$ \\
\hline & & Stdev. & & Stdev. & & Stdev. & & Stdev. & & Stdev. & & Stdev & & Stdev. & & Stdev & & Stdev & & Stdev & & Stdev. \\
\hline $\mathrm{SiO}_{2}$ & 28.99 & 0.22 & 37.89 & 0.40 & 47.53 & 1.01 & 47.91 & 1.59 & 34.27 & 0.43 & 37.19 & 0.20 & 44.922 & 0.365 & 57.02 & 0.52 & 54.93 & 1.27 & 57.27 & 1.21 & 59.67 & 0.68 \\
\hline $\mathrm{TiO}_{2}$ & 34.50 & 0.37 & 6.79 & 0.29 & 2.26 & 0.47 & 1.93 & 0.64 & 0.05 & 0.04 & 0.03 & 0.04 & 0.034 & 0.037 & 0.47 & 0.08 & 0.44 & 0.09 & 0.70 & 0.11 & 0.61 & 0.12 \\
\hline $\mathrm{Al}_{2} \mathrm{O}_{3}$ & 0.69 & 0.09 & 14.11 & 0.39 & 5.71 & 0.92 & 6.18 & 1.05 & 27.80 & & 30.15 & 0.34 & 33.114 & 0.249 & 20.63 & 0.17 & 21.11 & 0.21 & 18.63 & 0.25 & 17.69 & 0.55 \\
\hline $\mathrm{FeO}^{\text {total }}$ & 2.02 & 0.10 & 10.73 & 0.34 & & & & & 0.25 & 0.06 & 0.34 & 0.06 & 0.577 & 0.045 & 2.19 & 0.22 & 2.30 & 0.07 & 3.07 & 0.17 & 2.82 & 0.19 \\
\hline $\begin{array}{l}\mathrm{FeO} \\
\mathrm{Fe}_{2} \mathrm{O}_{3}\end{array}$ & & & & & $\begin{array}{l}3.99 \\
3.68\end{array}$ & $\begin{array}{l}0.36 \\
0.98\end{array}$ & $\begin{array}{l}3.50 \\
3.68\end{array}$ & $\begin{array}{l}0.75 \\
0.60\end{array}$ & & & & & & & & & & & & & & \\
\hline $\mathrm{MnO}$ & 0.22 & 0.03 & 0.13 & 0.05 & 0.21 & 0.15 & 0.11 & 0.04 & 0.02 & 0.02 & 0.02 & 0.03 & 0.013 & 0.013 & 0.16 & 0.07 & 0.22 & 0.05 & 0.28 & 0.06 & 0.24 & 0.05 \\
\hline $\mathrm{MgO}$ & 0.00 & 0.00 & 12.82 & 0.22 & 13.16 & 0.75 & 14.03 & 1.19 & 0.00 & & 0.01 & & & & 0.23 & & 0.17 & & & & & 0.10 \\
\hline $\mathrm{CaO}$ & 25.58 & 0.25 & 12.40 & 0.15 & 22.42 & 0.39 & 21.62 & 0.70 & 8.00 & 0.14 & 0.37 & 0.16 & 0.779 & 0.178 & 0.91 & 0.04 & 0.75 & 0.03 & 0.60 & 0.05 & 0.61 & 0.17 \\
\hline $\mathrm{BaO}$ & & & $\begin{array}{l}0.17 \\
256\end{array}$ & $\begin{array}{l}0.06 \\
0.07\end{array}$ & & & & & & & & & $\begin{array}{r}0.041 \\
1\end{array}$ & 0.044 & & & & & & & & \\
\hline $\begin{array}{l}\mathrm{Na}_{2} \mathrm{O} \\
\mathrm{K}, \mathrm{O}\end{array}$ & $\begin{array}{l}0.28 \\
0.01\end{array}$ & $\begin{array}{l}0.04 \\
0.02\end{array}$ & $\begin{array}{l}2.56 \\
0.88\end{array}$ & $\begin{array}{l}0.07 \\
0.06\end{array}$ & $\begin{array}{l}0.60 \\
0.01\end{array}$ & $\begin{array}{l}0.15 \\
0.00\end{array}$ & $\begin{array}{l}0.54 \\
0.00\end{array}$ & $\begin{array}{l}0.07 \\
0.01\end{array}$ & $\begin{array}{l}16.21 \\
0.89\end{array}$ & $\begin{array}{l}0.29 \\
0.13\end{array}$ & $\begin{array}{r}23.16 \\
1.77\end{array}$ & $\begin{array}{l}0.20 \\
0.14\end{array}$ & $\begin{array}{l}16.791 \\
3.42\end{array}$ & $\begin{array}{l}0.142 \\
0.156\end{array}$ & $\begin{array}{l}8.89 \\
5.89\end{array}$ & 0.10 & $\begin{array}{l}9.57 \\
5.54\end{array}$ & $\begin{array}{l}0.56 \\
0.16\end{array}$ & $\begin{array}{l}7.99 \\
4.98\end{array}$ & 0.55 & $\begin{array}{l}6.25 \\
4.55\end{array}$ & $\begin{array}{l}0.50 \\
0.21\end{array}$ \\
\hline 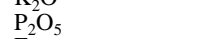 & & & $\begin{array}{l}0.88 \\
0.09\end{array}$ & $\begin{array}{l}0.00 \\
0.04\end{array}$ & & & & & & & & & & & $\begin{array}{l}3.89 \\
0.09\end{array}$ & 0.03 & 0.06 & 0.0 & & & 0.08 & 0.04 \\
\hline $\mathrm{F}$ & 0.21 & 0.03 & 0.16 & 0.02 & & & & & $\begin{array}{l}0.04 \\
0.52\end{array}$ & $\begin{array}{l}0.03 \\
0.02\end{array}$ & $\begin{array}{l}0.03 \\
5.37\end{array}$ & 0.03 & 0.057 & $\begin{array}{l}0.037 \\
0.010\end{array}$ & 0.21 & 0.11 & 0.23 & 0.0 & 0.22 & & 0.16 & 0.03 \\
\hline $\begin{array}{l}\mathrm{Cl} \\
\mathrm{S}\end{array}$ & & & $\begin{array}{l}0.02 \\
0.05\end{array}$ & $\begin{array}{l}0.01 \\
0.03\end{array}$ & & & & & $\begin{array}{l}0.52 \\
8.44\end{array}$ & $\begin{array}{l}0.02 \\
0.21\end{array}$ & $\begin{array}{l}5.37 \\
0.38\end{array}$ & $\begin{array}{l}0.10 \\
0.09\end{array}$ & 0.010 & 0.010 & $\begin{array}{l}0.42 \\
0.04\end{array}$ & $\begin{array}{l}0.06 \\
0.04\end{array}$ & $\begin{array}{l}0.52 \\
0.05\end{array}$ & $\begin{array}{l}0.07 \\
0.05\end{array}$ & $\begin{array}{l}0.31 \\
0.10\end{array}$ & $\begin{array}{l}0.07 \\
0.03\end{array}$ & $\begin{array}{l}0.28 \\
0.10\end{array}$ & $\begin{array}{l}0.07 \\
0.06\end{array}$ \\
\hline $\begin{array}{l}\mathrm{Cr}_{2} \mathrm{O}_{3} \\
\mathrm{NiO}\end{array}$ & & & & & $\begin{array}{l}0.06 \\
0.04\end{array}$ & $\begin{array}{l}0.05 \\
0.02\end{array}$ & $\begin{array}{l}0.15 \\
0.02\end{array}$ & $\begin{array}{l}0.12 \\
0.02\end{array}$ & & & & & & & & & & & & & & \\
\hline $\mathrm{ZrO}_{2}$ & 0.64 & 0.31 & & & & & & & & & & & & & & & & & & & & \\
\hline $\mathrm{Nd}_{2} \mathrm{O}_{3}$ & 0.79 & 0.10 & & & & & & & & & & & & & & & & & & & & \\
\hline $\begin{array}{l}\mathrm{V}_{2} \mathrm{O}_{3} \\
\mathrm{La}_{2} \mathrm{O}_{3}\end{array}$ & $\begin{array}{l}1.13 \\
0.52\end{array}$ & $\begin{array}{l}0.04 \\
0.07\end{array}$ & & & & & & & & & & & & & & & & & & & & \\
\hline $\mathrm{Ce}_{2} \mathrm{O}_{3}$ & 1.56 & 0.12 & & & & & & & & & & & & & & & & & & & & \\
\hline Total & 97.15 & 0.40 & 98.82 & 0.41 & 99.63 & 0.22 & 99.68 & 0.31 & 96.49 & 0.33 & 98.83 & 0.61 & 99.792 & 0.400 & 97.17 & 0.80 & 95.88 & 2.13 & 94.59 & 1.50 & 93.39 & 0.96 \\
\hline $\begin{array}{l}\mathrm{Fe}^{3} / \mathrm{Fe}^{2} \\
\mathrm{Mg} / \mathrm{Mg}+\mathrm{Fe}_{\text {total }} \\
\text { EN } \\
\text { FS } \\
\text { WO }\end{array}$ & & & & & $\begin{array}{r}1.068 \\
0.763 \\
43.623 \\
11.080 \\
45.298\end{array}$ & $\begin{array}{l}0.384 \\
0.033 \\
2.509 \\
2.011 \\
0.895\end{array}$ & $\begin{array}{r}0.896 \\
0.784 \\
47.245 \\
10.769 \\
41.987\end{array}$ & $\begin{array}{l}0.315 \\
0.032 \\
2.856 \\
1.700 \\
2.026\end{array}$ & & & & & & & & & & & & & & \\
\hline
\end{tabular}

Notes: Stdev. $=$ standard deviation. All values in weight percent. 
Table 4. ICP-MS analyses of pumice glasses.

\begin{tabular}{|c|c|c|c|}
\hline $\begin{array}{l}\text { Hole, core, section: } \\
\text { Interval }(\mathrm{cm}) \text { : } \\
\text { Depth }(\mathrm{mbsf}) \text { : }\end{array}$ & $\begin{array}{c}954 \mathrm{~A}-9 \mathrm{H}-4 \\
33-34 \\
72.33 \\
\end{array}$ & $\begin{array}{c}954 \mathrm{~A}-6 \mathrm{H}-5 \\
71-73 \\
45.71 \\
\end{array}$ & $\begin{array}{c}953 \mathrm{~A}-2 \mathrm{H}-5 \\
149-150 \\
15.09\end{array}$ \\
\hline \multicolumn{4}{|l|}{ Trace elements (ppm) } \\
\hline Sc & 1.77 & 0.95 & 1.57 \\
\hline $\mathrm{Cr}$ & 19.7 & 10.1 & 11.2 \\
\hline Co & 3.20 & 0.80 & 1.72 \\
\hline $\mathrm{Ni}$ & 7.83 & 2.11 & \\
\hline $\mathrm{Cu}$ & 10.7 & 5.60 & 7.80 \\
\hline $\mathrm{Zn}$ & 157.2 & 206.7 & 153.2 \\
\hline $\mathrm{Ga}$ & 35.7 & 37.8 & 41.8 \\
\hline $\mathrm{Rb}$ & 232.6 & 161.9 & 282.8 \\
\hline Cs & 3.49 & 2.05 & 4.62 \\
\hline $\mathrm{Sr}$ & 323.9 & 25.9 & 79.2 \\
\hline $\mathrm{Y}$ & 31.2 & 69.9 & 33.2 \\
\hline $\mathrm{Zr}$ & 1436 & 1300 & 1969 \\
\hline $\mathrm{Nb}$ & 236.4 & 360.9 & 304.4 \\
\hline $\mathrm{Ba}$ & 315.6 & 150.8 & 130.2 \\
\hline $\mathrm{La}$ & 142.1 & 219.0 & 138.4 \\
\hline $\mathrm{Ce}$ & 185.5 & 379.5 & 182.3 \\
\hline $\operatorname{Pr}$ & 14.4 & 37.0 & 13.9 \\
\hline $\mathrm{Nd}$ & 38.1 & 113.2 & 35.9 \\
\hline $\mathrm{Sm}$ & 5.12 & 17.7 & 5.08 \\
\hline $\mathrm{Eu}$ & 1.23 & 3.75 & 0.98 \\
\hline $\mathrm{Gd}$ & 4.60 & 14.24 & 4.57 \\
\hline $\mathrm{Tb}$ & 0.68 & 2.12 & 0.70 \\
\hline Dy & 4.09 & 11.8 & 4.40 \\
\hline Ho & 0.88 & 2.28 & 0.97 \\
\hline $\mathrm{Er}$ & 2.96 & 6.56 & 3.42 \\
\hline $\mathrm{Tm}$ & 0.50 & 0.92 & 0.60 \\
\hline $\mathrm{Yb}$ & 3.89 & 6.07 & 4.67 \\
\hline $\mathrm{Lu}$ & 0.63 & 0.85 & 0.75 \\
\hline Th & 38.0 & 28.9 & 55.9 \\
\hline $\mathrm{Ta}$ & 7.56 & 18.6 & 10.3 \\
\hline Hf & 25.7 & 25.5 & 35.4 \\
\hline $\mathrm{U}$ & 9.61 & 6.94 & 15.2 \\
\hline $\mathrm{Pb}$ & 23.0 & 16.1 & 29.2 \\
\hline
\end{tabular}



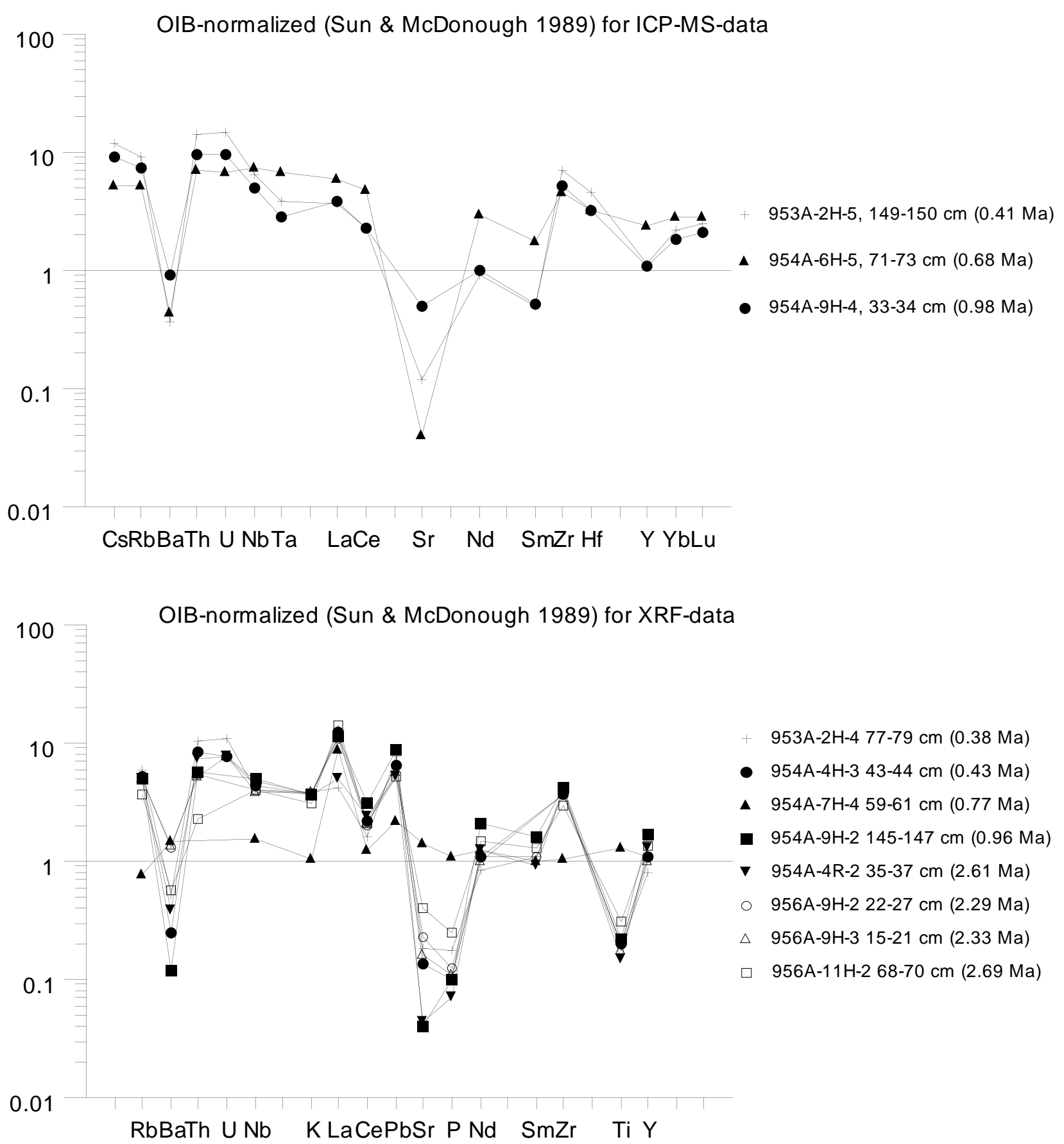

Figure 10. Trace element concentrations of several pumice glasses and tephra of basaltic composition (Sample 157-954A-7H-4, 59-61 cm; 0.77 Ma) analyzed by XRF. Three pumice samples were measured with ICP-MS. The data are normalized against OIB (Sun and McDonough, 1989). 